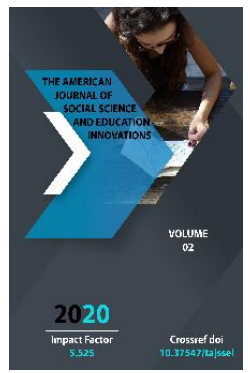

Journal Website: http://usajournalshub.c om/index,php/tajssei

Copyright: Original content from this work may be used under the terms of the creative commons attributes 4.0 licence.

\section{Modern State And Methods Of Enhancing The Productivity Of Field Progress In The South-Eastern Part Of Bukhara- Khiva Region}

\author{
Khayitov Odiljon G'afurovich \\ Candidate Of Geological And Mineralogical Sciences, Associate Professor, Head Of The \\ Department "Mining", 100095, Republic Of Uzbekistan, Tashkent, University Street, 2, \\ Tashkent State Technical University.
}

\title{
ABSTRACT
}

It is impossible to study the effect of PSS on CIN without using 7 statistical methods that allow not only to state the facts, but also, what is especially important, to find out the reasons why the influence of PSS on CIN varies in different mining and geological conditions of oil deposits.To date, a huge amount of material has been accumulated on deposits that are at the late and final stages of development, the synthesis of actual data on these deposits is of particular value for solving many controversial issues in the field of assessing the impact of certain technological solutions on the efficiency of implemented development systems.

\section{KEYWORDS}

Hydrocarbon, oil, gas, deposit, deposits, development efficiency, sub-gas reservoir, water pressure mode, horizontal well, productivity coefficient.

\section{INTRODUCTION}

Numerical experiments were carried out to assess the degree of influence of PSS on the value of $\neg$ KIN using statistical models obtained as a result of generalization of geological and commercial data of long-term developed deposits [11; 253p.]. One of the mainadvantages of statistical models obtained on 7 the basis of multivariate regression analysis is that they allow us to determine not only the qualitative, but also the quantitative influence of a particularnindicator on the process, while simultaneously influencing other factors. This is one of the main reasons why statistical models are used to estimate 
the impact of PSS on the KIN in various geological and physical conditions of deposits, and not just dependences between PSS and KIN values, which practically do not involve other geological and technological parameters.

The experience of using these models for estimating the KIN shows that relatively reliable results are obtained when they are used in conditions similar to those for which they were performed. They are only applicable in the range of parameters of objects and development systems used in obtaining statistical-models. Therefore, the statistical models given in the table below are used to estimate the degree of influence of PSS on KIN in sub-gas oil-deposits.Methodological guide for calculating oil recovery coefficients from the subsurface [11; 253p.], aswell $\neg$ as statistical models obtained for oil and gas facilities and fields with oil fringes of the South-West Siberian Federal DISTRICT.

\section{MATERIAL AND METHODS}

It is practically impossible to estimate the effect of the well grid density on the oil recovery coefficient using statistical models while simultaneously changing the value of all parameters, since this leads to multivariate calculations and POPs $\neg$ make it difficult to analyze the results obtained. In this regard, only the PSS value was changed in numerical experiments, and the other parameters $\neg$ of statistical models remained unchanged and equal to their average values. At the same time, the PSS value changed in the ranges used to obtain statistical models. The use of such a method is also explained by the fact that statistical models give the most reliable results when $\neg$ the parameters included in the dependencies are close to their average values[3; pp. 46-50, 5; c. 36-46].
The results of CIN calculations in the considered ranges of PSS change for each statistical model are presented in the form of dependencies shown in figure 1Atsame time for sub gas oil deposits with the prevailing water $\neg$ pressure regime the shave the form

$\mathrm{KIN}=\mathrm{abs},(1)$

And gashapons Regis IOM

$\mathrm{KIN}=\mathrm{a}-\mathrm{bS}+\mathrm{cS} 1(2)$

(wherea, b, C are the coefficients of dependencies) with sufficiently high correlation coefficients of $0.95-0.98$ and a low standard deviation of 0.022-0.055.

Analysis of the results of the evaluation of the degree of influence of PSS on CIN allows to draw some conclusions that should be considered in the design of oil oil deposits UVCHBKHR.

\section{RESULTS}

First, the oil recovery coefficients obtained from statistical models given in the Methodological guide for calculating oil recovery coefficients from the subsurface $a$ are significantly higher in all PSS ranges значительноthan вthose expected at the South-West Siberian oil and GAS condensate field. ᄀPossible reasons for such a large $\neg$ discrepancy may be related to the following-circumstances:

- the statistical models $\neg$ recommended in the Methodological guide were obtained in the period 1970-1980 for 7 deposits with the best geologicaland physical characteristics, due to which high KIN values were determined for them;

most statistical $\neg$ models in this period were obtained for the geological and physical conditions of depositsUral-Volga region and 
Azerbaijan. Using these dependencies for other regions, even if the parameters seemato match, may lead to an overestimation of the design QIN value.

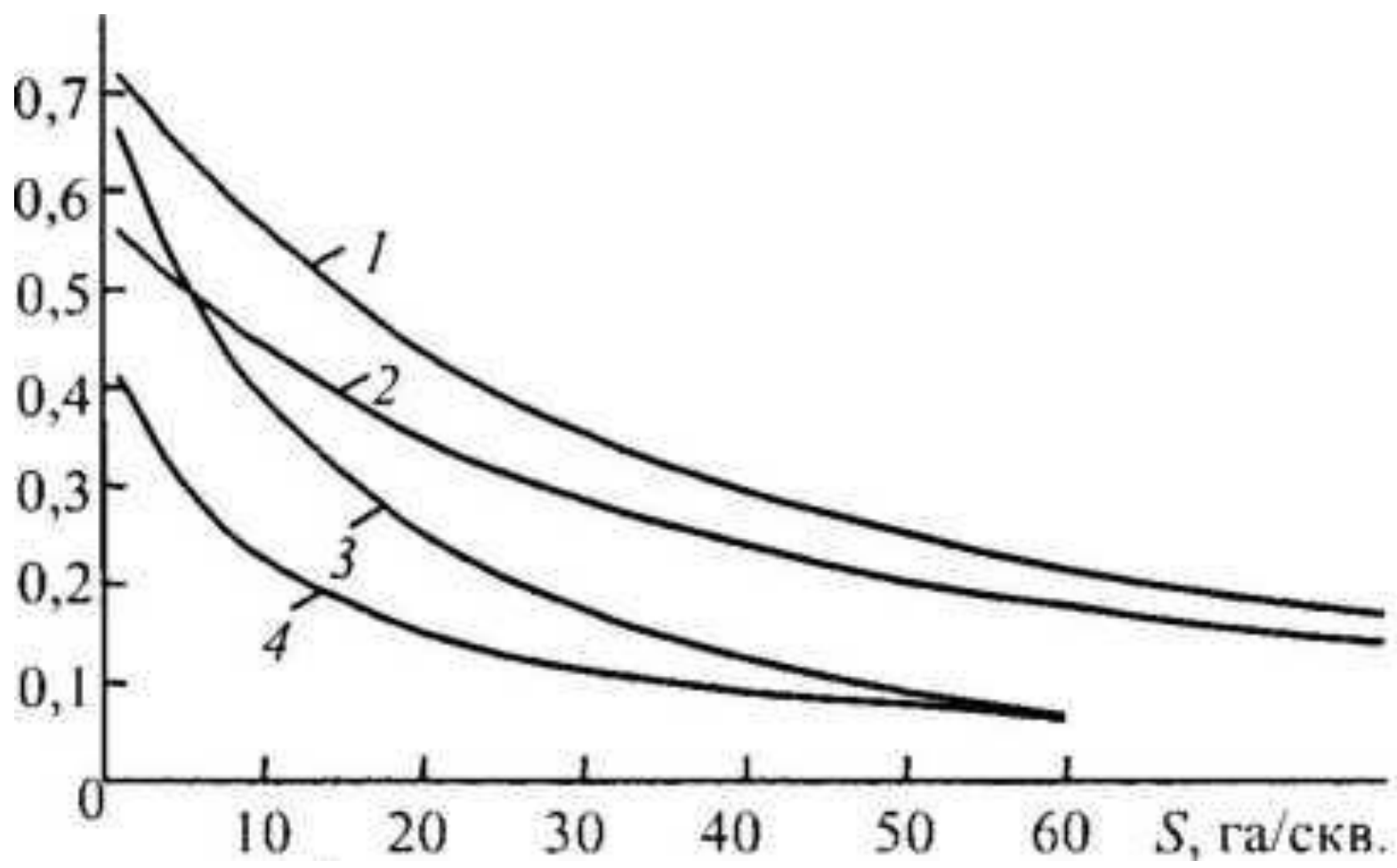

Fig.1. The dependenceof the oil recovery coefficient on the density of the well grid forvarious types of sub gas oil deposits: 1 - for oil rims with the prevailing indonnaperna mode; 2 - oil rims with the prevailing gasanaboblack mode; 3 - UVCHBKHRR for oil and gas deposits; 4 - oil rims UVCHBKHR.

Secondly, for oil fringes under the prevailing water-pressure regime, under other equal geological and physical conditions, the KIN is higher than under the gas-pressure 7 regime, which can be explained by a higher coefficientᄀof oil displacement by water compared to gas.

Third, a comparison of the oil recovery factor for oil and gas facilities and oil margins shows that the larger the volume of oil part $\urcorner$, the higher the value of the KIN.
Thus it is notnecessary to note that statistical models of KIN from PSS cannot replace the use of hydrodynamic models of the process isplace 7 tion of oil from the depths, carried out on the basis of three - and four-dimensional three-phase filtration, but they may be used when failure is the outcome of-experimental data, especially in the initial stage of industrial evaluation of the field, i.e. in the drafting phase of the project experimental-industrial exploitation, and to assess the effectiveness of compaction the density of the grid wells. 
Numerical experiments using formulas (2) and (3) show that theuse of traditional technologies with drilling of vertical wells in the development of such facilities does not provide acceptable technical and economic indicators, and the predicted values of the oil recovery factor rarely exceed 0,11-00,15 (table 1).

In this regard, the strategic direction of increasing the efficiency of developing subgas oil deposits with a small oil-saturated thickness is the use of new technologies. One of the most important achievements of oil and gas production in the world practice in the 2oth century is the drilling of horizontal wells. The 21st century was marked by great achievements in the technique and technology of building such wells at sufficiently deep depths [2; p .464].

Currently, there is a large number of works [12; c. 424, 13; c. 366, 14; c. 156 et al.], which cite positive and negative factors affecting the operation of horizontal wells. The main advantage of horizontal wells over vertical wells is that a horizontal shaft with a length of tens to thousands of meters can open areas with increased productivity or strongly fractured zones in an inhomogeneous formation. This explains the increased flow rate compared to the surrounding vertical wells.

Z. S. Aliev and V. V. Sheremet, using theoretical studies and analysis of the results of drilling horizontal wells in various oilproducing regions of the world, have established that their productivity coefficient is most influenced by three parameters: thickness of the formation (h), the length of the horizontal trunk ( $L$ )and the coefficient of anisotropy $(\beta)[15 ;$ c. 131$]$. In this case, under certain geological and physical conditions (combinations of $h, L$ and $\beta$ ), the productivity coefficient of horizontal wells (withg)m can be morethan 15 times higher than vertical wells ( with $\mathrm{BC}$ ) (Fig.2). The ratio fromg/sto b increases as $h$ decreases, $\beta$ and I increases. 


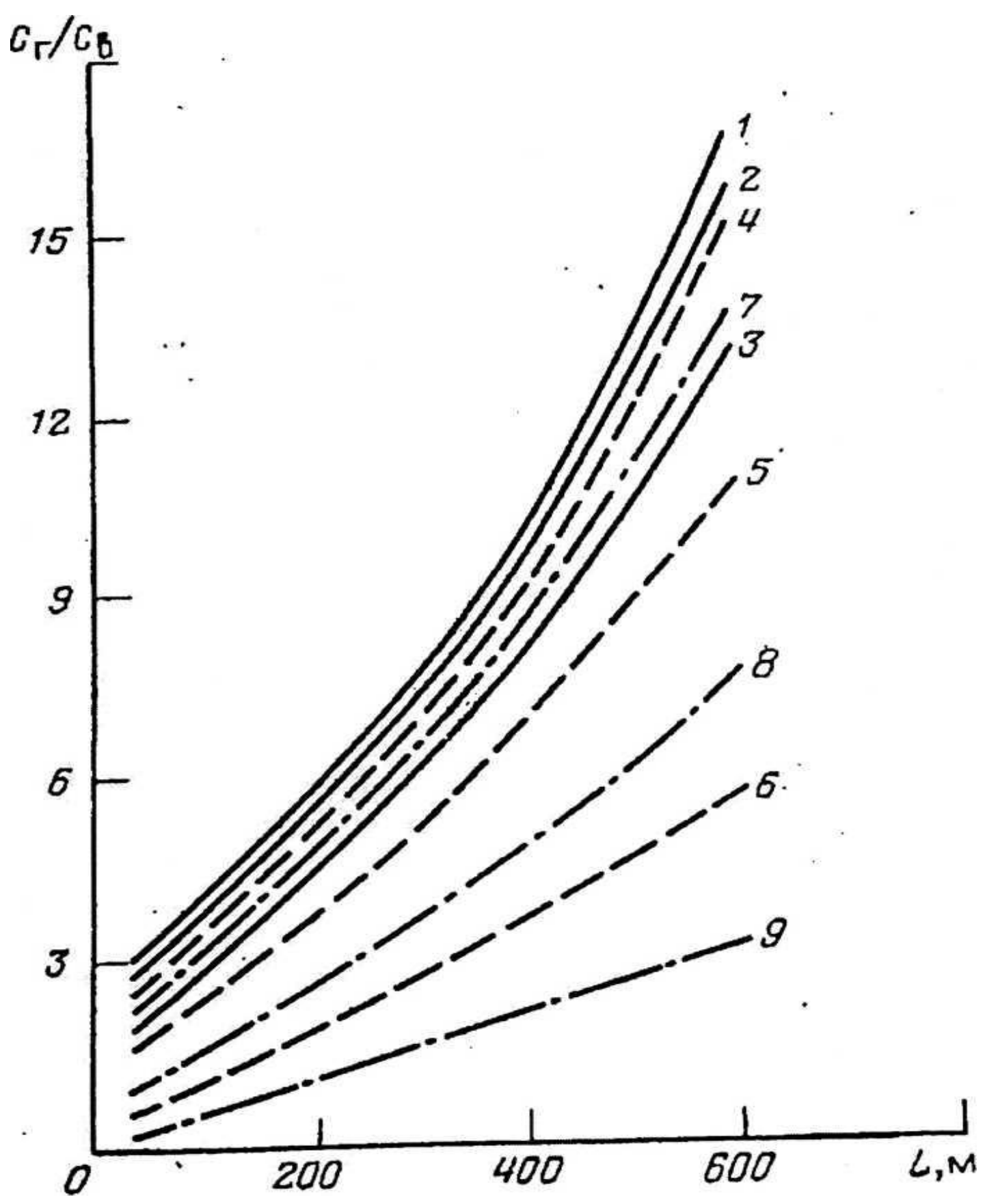

Fig.2. The dependence of the ratio of the coefficients of productivity horizontal From $_{g}$ and vertical With ${ }_{\text {in }}$ wells from the horizontal wellbore length $L$, thickness $h$ and the anisotropy parameter $ß: 1,2,3$ - h=6 m; $ß$, respectively $0,25,1,3 ; 4,5,6$ - h=30.5 m; $ß$ respectively $0,25,1,3 ; 7,8,9-h=61 \mathrm{~m} ; \mathrm{R}$, respectively $0,25,1,3$.

Analysis of the results of oil reservoir opening by horizontal wells drilled by various companies, and comparison of the flow rates of these wells with the vertical flow rates shows that in all cases the productivity of horizontal wells is $2-4$ times greater than the flow rate of vertical wells (table 1).Table 1 
Doi: https://doi.org/10.37547/tajssei/Volume02Issue09-65

\section{Comparison of flow rates of horizontal and vertical wells}

\begin{tabular}{|c|c|c|c|}
\hline Location of wells & $\begin{array}{l}\text { The company } \\
\text { is }\end{array}$ & $\begin{array}{l}\text { the Length of } \\
\text { the horizontal part, } \mathrm{m}\end{array}$ & Increasing the debit rate \\
\hline Michigan, United & $\begin{array}{c}\text { States "Trend- } \\
\text { Hawk's Well } \\
\text { OYL» }\end{array}$ & 76 & $\begin{array}{c}\text { Previously unproductive } \\
\text { well produced } 97.5 \mathrm{~m}^{3} / \mathrm{d} \text { of oil and } \\
17.2 \mathrm{~m}^{3} / \mathrm{d} \text { of gas }\end{array}$ \\
\hline Utah, USA & "Skiline-oil»" & $\begin{array}{c}67 \text { and } 145 \text { (two } \\
\text { horizontal barrels) }\end{array}$ & $\begin{array}{c}\text { Previously unproductive } \\
\text { well produced } 13.5 \text { thousand tons } \\
\text { of oil in two years }\end{array}$ \\
\hline Denmark & MAERSK line & $460-760$ & $\begin{array}{c}\text { Initial flow rates are } 2-4 \\
\text { times higher than in wells with a } \\
\text { vertical shaft }\end{array}$ \\
\hline $\begin{array}{l}\text { in the British sector of } \\
\text { the North sea }\end{array}$ & $\begin{array}{c}\text { " British } \\
\text { Petroleum" }\end{array}$ & 565 & $\begin{array}{l}\text { During the test' } 955 \\
\mathrm{~m}^{3} / \text { day of oil was obtained } \\
\text { (much more than the flow } \\
\text { rate of vertical wells) }\end{array}$ \\
\hline Willistonbasin, USA & " Meridian» & $610-1000$ & $\begin{array}{c}\text { Получены } 41-44 \mathrm{~m}^{3} / \text { day of oil and } \\
9,5 \text { thousand } \mathrm{m}^{3} / \text { day of gas were } \\
\text { obtained (in vertical wells of } 9,5 \\
\text { m²/day) }\end{array}$ \\
\hline $\begin{array}{c}\text { PradhoBay, Alaska, } \\
\text { United }\end{array}$ & $\begin{array}{l}\text { States " Standard- } \\
\text { Alaska- } \\
\text { Production house» }\end{array}$ & $300-490$ & $\begin{array}{c}\text { Initial productivity is } 3.5 \\
\text { times higher than in vertical } \\
\text { systems }\end{array}$ \\
\hline Javasea, Indonesia & "Arco»" & $\begin{array}{l}300-760 \text { (thin } \\
\text { layer) }\end{array}$ & $\begin{array}{c}\text { Coefficient } \\
\text { The productivity coefficient } \\
\text { of horizontal } \\
\text { wells is on average } 5.4 \text { times } \\
\text { higher than that of vertical wells }\end{array}$ \\
\hline Pearsell, Texas, United & States "Texenergo» & $43-808$ & $\begin{array}{c}\text { Oil production rate up to } 218 t \\
/ \text { day, gas } 1.8-26.8 \text { thousandm } 3 / \text { day }\end{array}$ \\
\hline
\end{tabular}


The world record for the length of the horizontal part of the barrel belongs to the company "Esso", which in 1980 in In the bass Bay of Australia, a well was drilled with a horizontal displacement of $46.66 \mathrm{~m}$. In the North sea, this record is equal to $4023 \mathrm{~m}$. Such a well was drilled in the Norwegian sector, and in the Gulf of Mexico, the largest length of the horizontal part of the trunk is $3379 \mathrm{~m}$ (the coast of Louisiana, 1983) [12; c. 424].

Currently, many firms are able to drill horizontal wells. Moreover, some of them, such as the firm "HPS(HorizontalProductionSystems)", have developed a technology for drilling multiple radial barrels from a single well. At the same time, first one horizontal well is drilled, after which radial trunks are drilled in the amount necessary for drainage of the formation. The company "HPS" drilled 10 radial wells with a total length of $1,275 \mathrm{~m}$ from the existing horizontal well bore in 1989 [12; p. 424].

We will show the high technological efficiency of horizontal wells in the studied sub gas oil deposits using the example of the Southern oil and gas condensate field Kemachi is also located on the UVCHBKHR.

Southern Field Kemachi was put into pilot operation in 1980 with wells Nos. 2 and 3.Until 2004, the development of the field was aimed at outstripping the production of the oil part of the Deposit. Because of the gas break to the current intervals of perforation in the oil part of the horizon, oil-producing wells were preserved. With such a system of development, the operation of the field became economically impractical. In this regard, to increase the production of liquid hydrocarbons in 2004, a decision was proposed to switch to joint development of the oil and gas condensate parts of the
Deposit, with one interval of perforation, a single grid of wells [16; p. 295].

The implemented development system as a whole proved insufficiently inefficient for the following reasons [17; p. 382].

- transfer of wells to the gas production Fund for the operation of the gas cap leads to irrational consumption of reservoir energy and as a result, a significant share of recoverable oil reserves may be lost;

- in General, the installation of down hole devices "CODS" ( GMG International, USA) and down hole of the fittings had a positive effect. But the effect of their use was often short-lived. To extend the effect of the applied technology, it is necessary to systematically make changes in the operation of wells, including for wells where the technology in question was not used, to ensure an optimal technological regime;- the technology of works on isolation of waterflows, consisting in isolation of the existing and transition to the upper interval, with a small thickness of the oil border is ineffective. The oil and gas production interval is often transferred to the gas production Fund of wells. The absence of modern methods and means of selective isolation is accompanied by the loss of recoverable oil reserves.

In 2007, in order to increase the rate of selection and the final coefficient

oil recovery at the southern gas condensate field Kemachi has drilled horizontal wells no. 54g, 59g, 74g.

As can be seen from Fig. 3 horizontal wells were drilled in the oil bearing zone with a thickness of 8-10 $\mathrm{m}$ of the oil border. 
The analysis of the efficiency of operation of horizontal wells № 54g, 59g, $74 \mathrm{~g}$ by comparing their performance with the performance of vertical wells located in similar conditions is presented in table 2 .

Table 2

Table of comparison of performance characteristics of horizontal and vertical wells.

\begin{tabular}{|c|c|c|}
\hline Indicator name & $\begin{array}{c}\text { Average value for vertical } \\
\text { wells no. 56, } \\
58.61,68.71,73.94\end{array}$ & $\begin{array}{c}\text { Average value for } \\
\text { horizontal wells no. } \\
54 \mathrm{~g}, 59 \mathrm{~g}, 74 \mathrm{~g}\end{array}$ \\
\hline Initial average daily oil production rate, $\mathrm{t} / \mathrm{d}$ & 13 & 55 \\
\hline Average water loss for the entire period, $\%$ & 54 & 46 \\
\hline Average gas factor, thousand $\mathrm{m}^{3} / \mathrm{t}$ & 23 & 9 \\
\hline Average well operation time, years & 6 & 5 \\
\hline
\end{tabular}

\section{DISCUSSIONS}

Analysis of the results of operation of medium horizontal and vertical wells revealed a greater efficiency of the first (table 1). 5).The initial average daily oil production rate of an average horizontal well is 4.4 times higher than that of an average vertical well. The accumulated oil production of an average horizontal well is 4.6 times greater than that of an average horizontal well, although theaverage operating time of a horizontal well is less ( 5 versus 6 years). In addition, the average gas factor and water cut (from the accumulated values) of horizontal wells is less by 2.6 times and 1.2 times, respectively.

Since horizontal wells had a lower rate of water flow and free gas breakout, i.e. their specific energy consumption is less, and their oil production significantly exceeded that of vertical wells, the high efficiency of their application is obvious.

\section{CONCLUSIONS}

Naturally, in the initial stage, special emphasis is placed on the types of research 7 aimed at determining and justifying the estimated parameters $\neg$ of carbon dioxide reserves. This leads to the fact that in the preparation of project documents for development of oil fields with application of hydrodynamic calculation methods, based on mathematical description of mechanism of process oil recovery and requires the use of a wide range of settings, acute lacked-the ka of data on reservoir permeability, the change in the value of oil properties and gas pressure, phase and relative permeability, of the geological heterogeneity parameters of layers etc. Under 
these conditions, the use empirical formulas becomes not only unavoidable, but also significant for making management decisions in the initial stage of development.

\section{REFERENCES}

1. Nazarov U. S. Project of joint development of oil and gas condensate parts of the Deposit of the Yuzhny Kemachi field. - Tashkent: JSC "Uzlitineftgaz", 2004.

2. Karshiev O. A., Boydedaev A. A., Zorin A. A., Derevyanko T. V., Mamadaliev B. T. Prospects of oil and gas content of Jurassic terrigenous deposits of the Beshkent trough and the SouthWestern spurs of the Hissar ridge / / Oil and gas Geological science of Uzbekistan and the role of youth in solving its problems// Materials of the scientific conference. "Works of young scientists. Issue 4". - Tashkent: JSC "IGIRNIGM", 2015. - 132 p.

3. Methodological guide for calculating the coefficients of oil recovery from the subsurface: RD 39-0147035-214-86 Moscow: vniii, 1986. 253 p.

4. Suchkov B. M. Horizontal wells. Moscow-Izhevsk: SIC "Regular and chaotic dynamics", 2006. - 424 p.

5. Yurkiv N. I. Physical and chemical bases of oil recovery. - M.: JSC "VNIIOENG", 2005. 366 p.

6. Yartiev A. F., Fazlyev P. T., Mironova L. M. Application of horizontal wells in oil fields of Tatarstan. - M.: JSC "VNIIOENG", 2008. -156 p.

7. Aliyev 3. C., Sheremet V. V. Determining the productivity of horizontal wells that have opened gas and oil reservoirs. - Moscow: Nedra, 1995. - $131 \mathrm{p}$.

8. Hayitov O. G., NabiyevaN. To., Mahmudov Sh. N. The evaluation of the impact of well spacing on oil recovery factor oil of oil deposits. // "Izvestiya vuzov. Mining journal". Uralsky: 2013, No. 6, Pp. 46-50.

9. Abdullaev G. S. Features of the geological structure of the Jurassic carbonate deposits of the Northflowing part of the Beshkent trough and associated prospects for oil and gas potential. - T.: Uzbek journal of oil and gas, 2010. no. 4. - P. 10-12.

10. Muratov A. S. Prospects for detecting oil and gas deposits in the Northern part of the Beshkent trough of the Bukhara-Khivn region. - T.: Uzbek journal of oil and gas, 2010, no. 4. - P. 13-16.

11. Evseeva G. B. the Role of foraminifera in the development of stratigraphic schemes of the Jurassic carbonate formation of the Bukhara-Khivn region. - T.: Uzbek journal of oil and gas, 2007, no. 3. - P. 23-26.

12. Karshiev O. A., Abbasova S. A. Features of the zonal change of the "Uglevodorod-Voda" contact in the Western part of the Beshkent deflection of the Kamashinsky Val and Karatepinsky uplift. - T.: Uzbek journal of oil and gas, 2014, no. 4. - Pp. 14-17.

13. Karshiev O. A., Abbasova S. A. New data on the geological structure and oil and gas content of the Eastern slope of the Dengizkul subdistrict of the Bukhara-Khivn region. - T.: Uzbek journal of oil and gas, 2016, no. 4. - Pp. 20-24

14. Megliev F.E. Features of the tectonic structure of the North-Eastern part of the Beshkent trough and its connection with oil and gas capacity. T.: Uzbek journal of oil and gas, 2005, no. 3. - Pp. 10-13.

15. Megliev F.E., Gulyamova A.K. Isolation and development of complex reservoirs in carbonate rocks of the Beshkent trough. - T.: Uzbek journal of oil and gas, 2003, no. 2. - P. 13-15. 
16. Lysenko V. D. Problems of designing the development of zonal heterogeneous oil fields. 2007 . No. 11. Pp. 15-17.

17. Agzamov A. A., Khayitov O. G., Karshiev A. $H$. on the degree of influence of the rate of liquid selection on the rate of oil selection at various stages of development of deposits represented by carbonate reservoirs. // "Izvestiya vuzov. Mining journal». Uralsky. 2016. no. 4-P. 36-46.

18. Hayitov O. G. Yusupkhodzhaeva E.N. Abdurakhmanova S.P. Halmatova G.N. ON THE STATE OF HYDROCARBON RESOURCE BASE IN THE BESHKENT TROUGH On the state of hydrocarbon resource base in the Beshkent trough. $-\mathrm{P}$ -

23272331.https://www.jardcs.org/abstr act.php?id=5787. 